\title{
FORAGING ACTIVITY OF MANAGED BEE POLLINATOR (Apis cerana indica) IN BITTER GOURD CROPPING SYSTEM IN INDIA
}

\author{
Hindistan'da Acı Kabak Yetiştirme Sisteminde Bakılmış Arı Tozlayıcısının (Apis \\ cerana indica) Yayılma Faaliyetleri
}

\section{Narmadha KAMATCHI MURALI', Saravanan PERNAMALLUR AYYASWAMI², Umapathy GOVINDASAMY ${ }^{3}$, Velmurugan MUTHUSAMY ${ }^{4}$}

\begin{abstract}
${ }^{1}$ Department of Agricultural Entomology, Tamil Nadu Agricultural University, Coimbatore 641-003, Tamil Nadu, INDIA. ORCID No: 0000-0002-2007-036X, Yazarı/Corresponding author E-mail: narmadhakm@gmail.com

${ }^{2}$ Tapioca and Castor Research Station, Yethapur, Salem 636-119, Tamil Nadu, INDIA. ORCID No: 0000-0001-8789-4497, Email: entosaravanan@gmail.com

${ }^{3}$ Centre for Plant Protection Studies, Tamil Nadu Agricultural University, Coimbatore 641-003, Tamil Nadu, INDIA. ORCID No:0000-0002-5616-4544, Email: umapathy@tnau.ac.in

${ }^{4}$ Department of Floriculture and Landscaping, Tamil Nadu Agricultural University, Coimbatore 641-003, INDIA. ORCID No: 0000-0002-4196-2877, Email: hortmrvelu@gmail.com
\end{abstract}

Geliş Tarihi / Received: 26.09.2021Ｋabul Tarihi / Accepted: 17.10.2021 DOI: 10.31467/uluaricilik.1000935

\begin{abstract}
Honey bees play an important role in crop pollination of bitter gourd flowers. An experiment was conducted at Coimbatore District to observe the foraging activity and pollination efficiency of Indian bee ( $A$. cerana indica) in Bitter gourd (Momordica charantia L.). The foraging activity and number of foragers/ flower/ min was recorded in male and female bitter gourd flower. Bitter gourd fruit set and yield was assessed under three conditions pollinator exclusion, bee pollination and open pollination. No. of foragers/ flower/ minute (abundance of pollinators) and floral handling time in seconds (foraging rate) of Indian bees recorded on male flower $(0.88$ bees) and $(6.52 \mathrm{sec})$ was higher than in female flower $(0.57$ bees) and $(3.61 \mathrm{sec})$ respectively. The peak foraging activity of $A$. cerana indica noticed between 08:00-10:00 hours with 1.2 foragers/ 5 mins. Pollination efficiency index of Indian bee was 747035.5. Foraging activity at the hive entrance was maximum at 08:00 to 10:00 hours. Colony growth parameter of $A$. cerana indica was increased $67.85 \%$ in respect of the sealed honey area and $15.07 \%$ in respect of the adult population. The results of pollination studies show, the number of fruits/plant (17.4 fruits) and fruit yield per hectare $(41.13 \mathrm{t} / \mathrm{ha})$ was higher in managed bee pollinated plot than to open pollination condition (16.2 fruits) and (37.25 t/ha) and no fruit set was recorded in pollination exclusion condition.
\end{abstract}

Key words: Bitter gourd, Apis cerana indica, foraging activity, pollination efficiency

ÖZ

Bal arıları, acı kabak çiçeklerinin mahsul tozlaşmasında önemli bir rol oynamaktadır. Acı kabakta (Momordica charantia L.) Hint arısının (A. cerana indica) yiyecek arama aktivitesini ve tozlaşma etkinliğini gözlemlemek için Coimbatore Bölgesinde bir deney yapılmıştır. Erkek ve dişi acı kabak çiçeğinde yiyecek arama aktivitesi ve toplayıcı/çiçek/dk sayısı kaydedilmiştir. Acı kabak meyve tutumu 


\section{ARAŞTIRMA MAKALESI / RESEARCH ARTICLE}

ve verimi, tozlayıcı dışlama, arı tozlaşması ve açık tozlaşma olmak üzere üç koşul altında değerlendirilmiştir. Hint arılarının erkek çiçek (0.88 arı) ve (6.52 sn) dişi çiçekten (0.57 arı) daha yüksek olduğu kaydedilmiştir. (3.61 sn) sırasıyla. A. cerana indica'nın pik arama aktivitesi, 1.2 toplayıcı / 5 dakika ile 08:00-10:00 saatleri arasında fark edildi. Hint arısının tozlaşma verimlilik indeksi 747035,5 olmuştur. Kovan girişinde yiyecek arama faaliyeti en fazla 08:00-10:00 saatleri arasında olmuştur. A. cerana indica'nın koloni büyüme parametresi kapalı bal alanına göre $\% 67.85$, ergin popülasyona göre ise \%15.07 artmıştır. Tozlaşma çalışmalarının sonuçları, idareli arı ile tozlanan parsellerde meyve/bitki sayısı (17,4 meyve) ve hektar başına meyve veriminin $(41,13 \mathrm{t} / \mathrm{ha})$, açık tozlaşma koşuluna $(16,2 \mathrm{meyve})$ ve $(37,25 \mathrm{t} / \mathrm{ha})$ göre daha yüksek olduğunu göstermektedir ve tozlaşma dahil edilmedğinde hiçbir meyve tutumu kaydedilmemiştir.

Anahtar kelimeler: Acı kabak, Apis cerana indica, yiyecek arama etkinliği, tozlaşma etkinliği

\section{GENIŞLETILMIŞ ÖZET}

Çalışmanın amacı: Çalışmanın amacı, Hindistan'daki acı kabak yetiştirme sisteminde bal arısı Apis cerana indica'nın yiyecek arama aktivitesini ve tozlaşma etkinliğini değerlendirmekti.

Malzemeler ve yöntemler: Çalışma Coimbatore ilçesinde yürütülmüş, tozlayıcıların yiyecek arama faaliyetlerini incelemek için on bitki rastgele etiketlenmiş ve bitki başına 3 çiçek haftalık aralıklarla gözlemlenmiştir.

Tozlayıcının pik aktivitesi sırasında yiyecek arama davranışı hayır olarak kaydedildi. toplayıcılar /çiçek/dakika (tozlayıcıların bolluğu) ve bireysel arı tozlayıcısı/çiçek/dakika (toplayıcılık oranı) tarafından haftalık aralıklarla bir kronometre kullanılarak harcanan süre ve no. 0600-1800h arasında iki haftada bir 5 dakikalık bir süre boyunca ziyaret eden/çiçek açan toplayıcıların oranı. Arı gövdelerindeki gevşek polen taneleri ölçülmüş ve no. vücuttaki gevşek polen taneleri $\times$ yiyecek arama oranı $\times$ acı kabak çiçekleri üzerindeki tozlayıcıların bolluğu.

Yönetilen arıların tozlaşma verimliliği, tozlayıcı dışlama (T1), arı tozlaşma (T2) ve açık tozlaşma koşulunda (T3) olduğu gibi farklı tozlaşma modlarında değerlendirildi, verim değerlendirmesi yapmak için çiçeklenme başladıktan sonra tedavi başına 350 dişi çiçek etiketlendi. Kovan girişinde yiyecek arama faaliyeti 08:00-10:00, 12:00-13:00 ve 16:00-18:00 saatleri arasında 5 dakika süre ile sayılmıştır. Koloni büyüme parametreleri, $1 \mathrm{~cm} 2$ 'lik şeffaf OHP levha ızgara yöntemi kullanılarak numaralandırıldı.

Sonuçlar: Acı kabak, erkek ve dişi çiçek oranı 25:1 olan tek evcikli bir mahsuldür ve genellikle açık tozlaşma koşullarında (bal arılarının daha az aktivitesinden dolayı) zayıf tohumla sonuçlanır. Bu çalışma sonucunda A. cerana indica'nın çiçek üzerinde gözlemlenen aktivitesinin 06:00-10:00 saatleri arasında zirve yaptığı ve 17:00-18:00 saatleri arasında herhangi bir aktiviteye rastlanmadığı ortaya çıkmıştır. A. cerana indica, verimi ve meyve tutumunu arttırdığı için acı kabak ekosisteminde etkili tozlayıcı olarak kabul edilmiştir. Kovan girişindeki aktivite, toplayıcıların maksimum hareketinin 08:00-10:00 saatleri arasında gözlemlendiğini ve deney süresi boyunca koloni büyümesinin kapalı bal alanına göre $\% 67.85$ ve ergin popülasyona göre $\% 15.07$ olduğunu göstermiştir. Meyve tutumu (17,4/bitki), meyve ağırlığı (255,3 g/meyve) ve 41.3t/ha verim, açık tozlaşmaya kıyasla kontrollü arı tozlamalı parselde maksimum olmuştur.

Çözüm: Mevcut çalışmamız, A. cerana indica ile yönetilen arı tozlaşma koşulunda, açık tozlaşma koşulu ve tozlayıcı dışlama gibi diğer tozlaşma modlarıyla karşılaştırıldığında, daha yüksek meyve tutumu ve meyve ağırlığı açısından farklı tozlaşma modlarının verim değerlendirmesinin gözlemlendiğini ortaya koymuştur. tozlayıcı hariç tutma durumunda, meyve tutumu kaydedilmemiştir.

\section{INTRODUCTION}

Pollination deficit is commonly noticed in many cucurbits, due to monoecious nature of flowering, which warrants the role of pollinators for fruit set and quality seed development. Honey bees play a crucial role in $80 \%$ crop pollination and at the same time contribute to the production of 1.6 million tonnes of honey (FAO, 2015). Managed bee pollination with $A$. cerana indica colonies increase the seed yield in many agricultural and horticultural crops, as for example for sunflower $79 \%$, for mustard $55 \%$, for safflower $64 \%$, for coconut $40 \%$, for gourds and for 


\section{ARAŞTIRMA MAKALESI / RESEARCH ARTICLE}

litchi $20 \%$. The estimated losses due to insufficient pollination in India were about Rs. 10,000 to Rs. 55,000 per hectare in cross pollinated crops (Mohapatra et al. 2019).

Bitter gourd (Momordica charantia L.) is widely cultivated in Tropical and Sub Tropical countries and popularly is called ampalaya, balsam pear, karela or bitter cucumber. In bitter gourd the male flower (staminate) blooms first followed by female flowers (pistillate) in the ratio of 19:12 (Deyto and Cervancia 2009) or 25:1 (Deshpande et al. 1979). Anthesis starts between 3.30 am to 7.30 am (Pal and Maurya 1972) and stigma receptivity lasts for $24 \mathrm{~h}$ after anthesis. The bright yellow color flower attracts many pollinators. The flat structure and the opening position of the flower favours them for easy access to pollen and nectar. In bitter gourd, honey bees were the most dominant pollinator which constitutes $74.98 \%$ followed by other pollinators such as lepidopterans $(4.92 \%)$, coleopterans $(3.58 \%)$, dipterans (4.35\%) and hemipterans (3.19\%) (Jignesh and Pastagia 2021). Fruit development starts from second to fifth day after pollination and insufficient pollination leads to drying of fruit on fifth day or results in curling of fruit which affects the marketable quality of the fruit. Hence, an experiment was conducted, to study the foraging activity, to measure the pollen grains on bee bodies and the colony growth of managed bees and to evaluate the pollination potential of Asiatic hive bees in bitter gourd.

\section{MATERIALS AND METHOD}

A field experiment was conducted at Telugupalayam area of Coimbatore District in India during 2021, to study the foraging behaviour of $A$. cerana indica; for this, ten plants were randomly tagged and 3 flowers per plant was observed at weekly intervals

\section{Foraging activity of managed bee pollinators on bitter gourd flowers}

Abundance of pollinators was recorded as no. of foragers/ flower/ minute and foraging rate as time spent by individual bee pollinator/ flower/ minute on both male and female flowers; both were recorded using a stopwatch at weekly intervals during peak pollinator activity. Peak foraging activity was recorded at an hourly interval from 06:00-18:00 h no. of foragers visited/flower for a period of 5 minutes at fortnightly interval (Yogapriya et al. 2019).

\section{Pollination efficiency index}

Loose pollen grains were counted by collecting foraging bees in the field at peak hours of foraging between 08:00 $\mathrm{h}$ and 10:00 $\mathrm{h}$ using a sweep net and bees are transferred to a glass vial containing $70 \%$ alcohol, shaken vigorously to unload the pollen grains from their body. Volume made up to $5 \mathrm{ml}$. An aliquot of $0.01 \mathrm{ml}$ was taken and observed under a microscope by using a haemocytometer. Repeated for 5 replications and the total number of pollen grains in $5 \mathrm{ml}$ of solution were calculated (Kumar et al. 2012).

Pollination Efficiency Index $=$ No. of loose pollen grains on the body $\times$ foraging rate $\times$ abundance of pollinators on bitter gourd flowers.

\section{Evaluation of pollination potential of managed bee pollinators}

The yield of bitter gourd was assessed with different modes of pollination. The experiment was conducted in Randomized Block Design (RBD) with three treatments and seven replication, 5 plants per replication (10 female flower per plant totally 350 flowers) were tagged after initiation of flowering to carry out yield assessment. Treatments included a) pollinator exclusion (T1), where female flowers were covered with sleeve cages before it begins to bloom (Fig. 1); one week after flowering the cages were removed; b) bee pollination (T2), where three frame strength Indian bee colonies were shifted to bitter gourd field in Telugupalayam, at the time of initiation of flowering in $10 \%$ plants; c) while open pollinated condition (T3) which was considered as control.

\section{Yield parameters}

\section{Number of fruits per plant, fruit weight and yield}

The number of fruits in tagged plants were counted and the fruit weight recorded. Randomly harvested ten fruits from tagged plants were weighed using a weighing balance and fruit weight was recorded. Fruits in each tagged plant were harvested, weighed and the yield was calculated and converted into yield per hectare (Manchare et al. 2019).

\section{Foraging activity of $A$. cerana indica at hive entrance}

The number of returning foragers with nectar (corbicula without pollen), pollen (corbicula with pollen) and number of outgoing foragers at the hive entrance was counted for the day during 08:00- 


\section{ARAŞTIRMA MAKALESI / RESEARCH ARTICLE}

10:00 h, 12:00-13:00 $\mathrm{h}$ and 16:00-18:00 $\mathrm{h}$ for a period of 5 minutes.

\section{Colony growth of $A$. cerana indica placed in bitter gourd field}

Colony growth parameters as for example sealed brood area, sealed honey area, pollen storage area and adult bee population were enumerated using transparent $\mathrm{OHP}$ sheet grid of $1 \mathrm{~cm}^{2}$ and observations recorded at 15 days interval, \% increase in colony growth parameters was compared (Fig. 2).

\section{Statistical Analysis}

Data were analyzed using the ANOVA (Analysis of Variance) and least significant difference (LSD) was performed at $\mathrm{P}=0.05$ levels of significance. All other calculations are performed using the MS Excel.

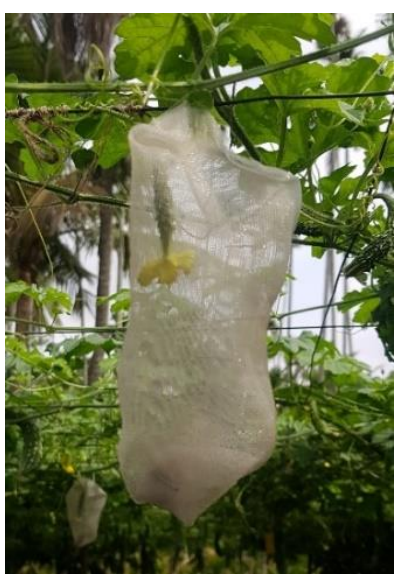

Figure 1: Sleeve cage

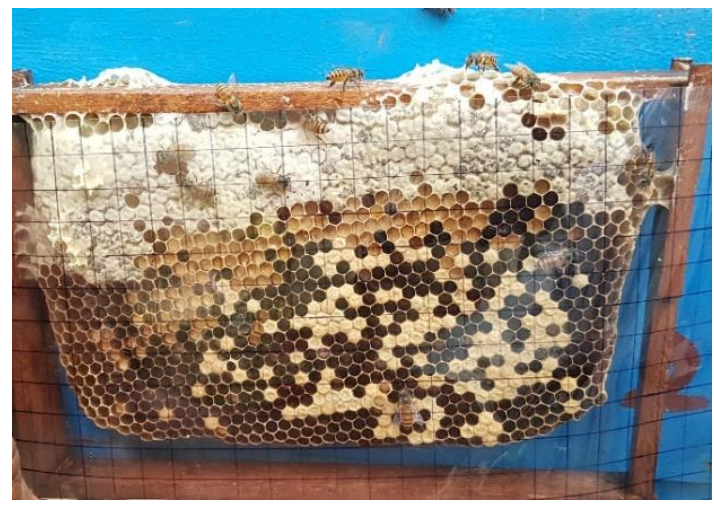

(a)

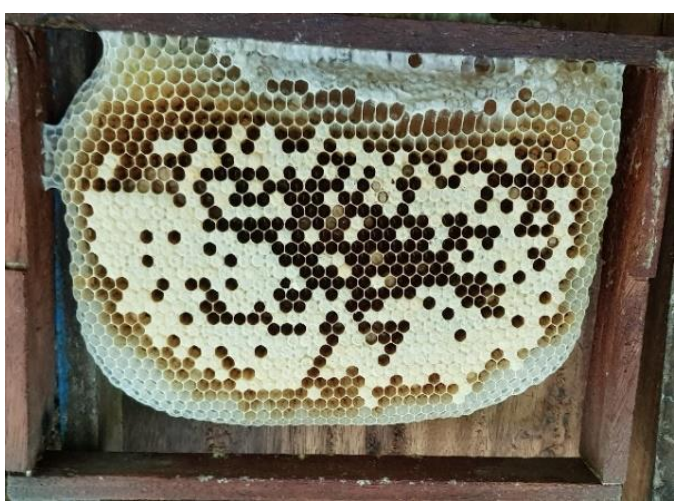

(b)

Figure 2: Colony growth parameter by OHP sheet gird method

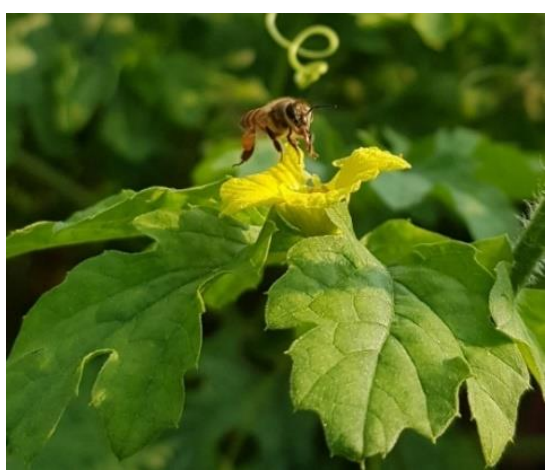

(a)

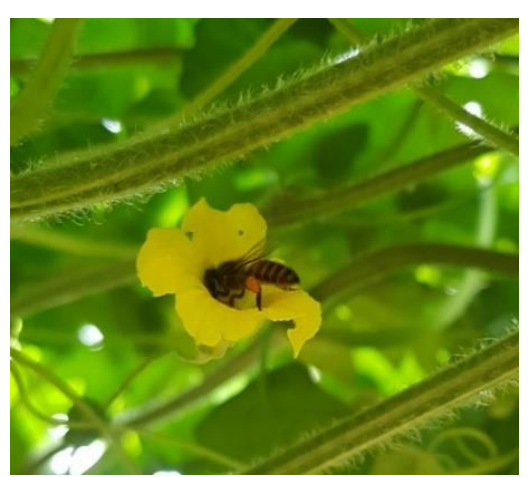

(b)

Figure 3: Foraging activity of Indian bee on bitter gourd flowers 


\section{ARAŞTIRMA MAKALESI / RESEARCH ARTICLE}

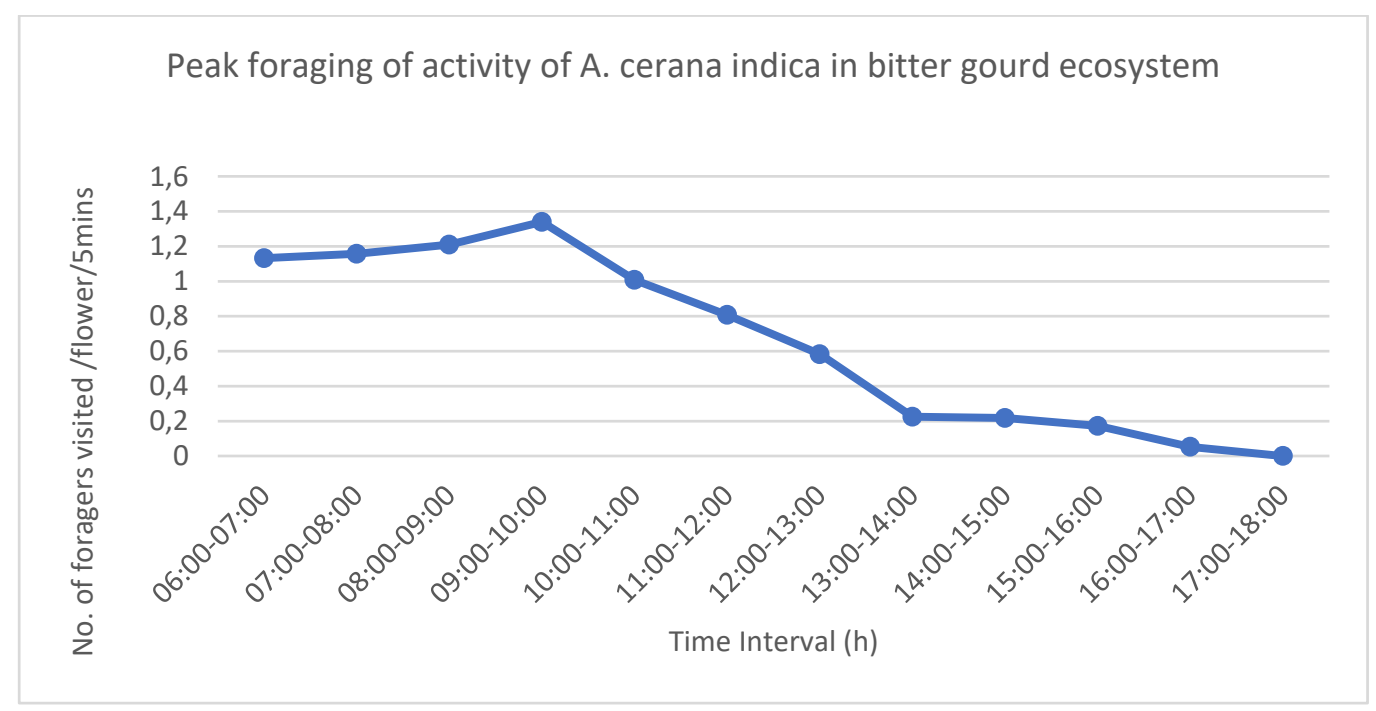

Figure 4: Peak foraging of Indian bees in bitter gourd

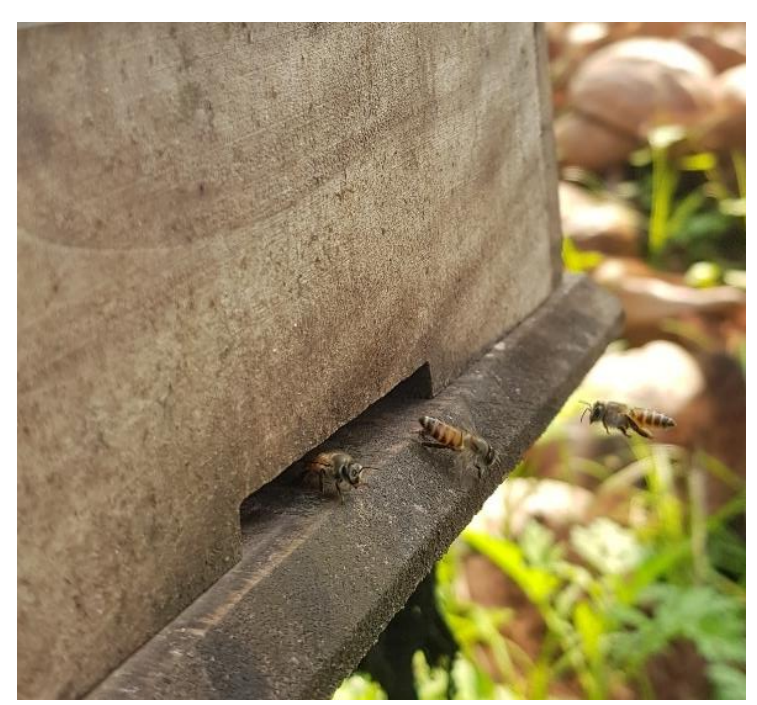

(a) Incoming nectar forager and outgoing bees

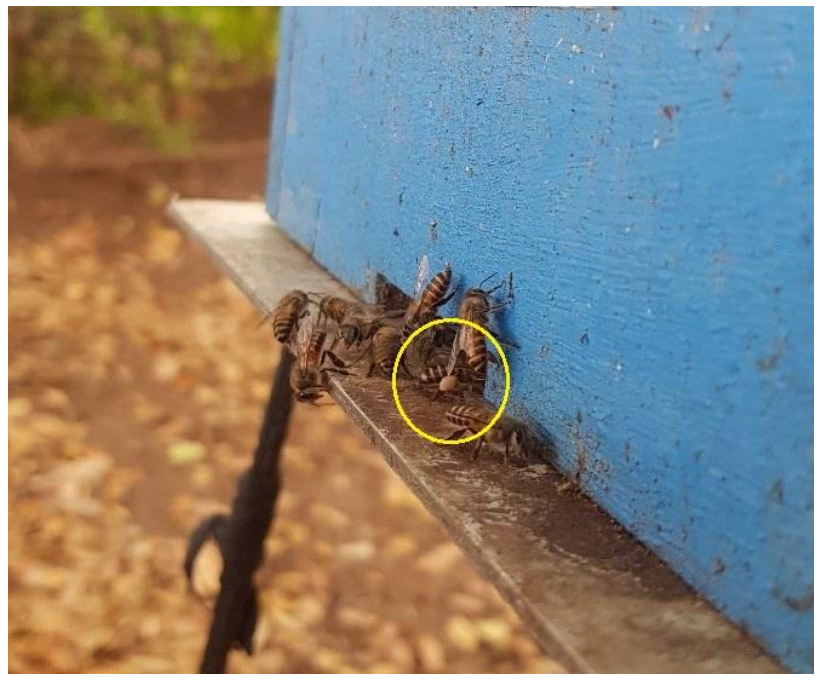

(b) Incoming forager with pollen load in corbicula

Figure 5: Foraging activity at the hive entrance 


\section{ARAŞTIRMA MAKALESİ / RESEARCH ARTICLE}

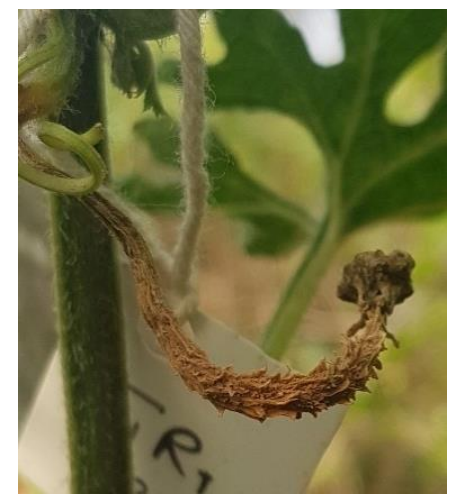

(a1)

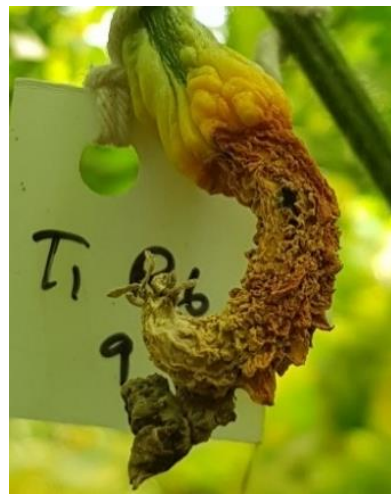

(a2)

(a) Pollinator exclusion

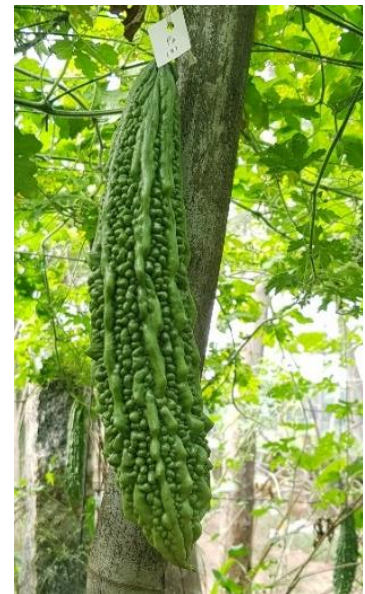

(b1)

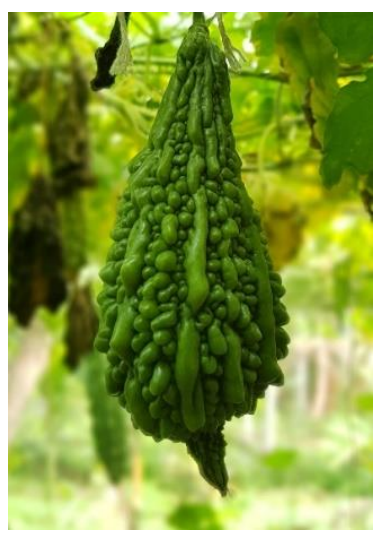

(c1)

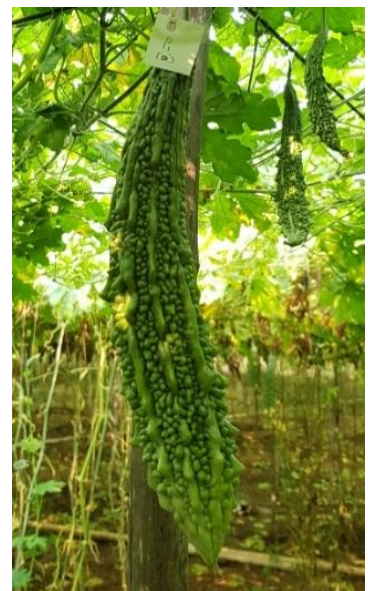

(b2)

(b) Bee pollination

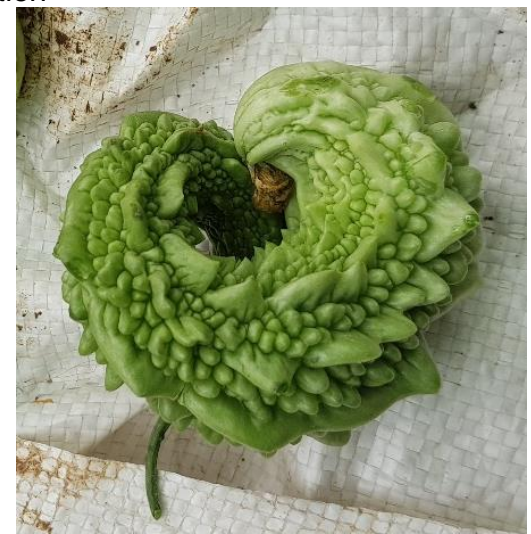

(c2)

(c) Open pollinated condition

Figure 6: Fruit set in different mode of pollination 


\section{ARAŞTIRMA MAKALESI / RESEARCH ARTICLE}

\section{RESULTS}

The result of the foraging activity of $A$. cerana indica showed that the abundance of forager bees was higher in male flower than female flowers (Table 1). The maximum number of bees in male flower were $1.15 \mathrm{bees} / \mathrm{flower} /$ minute and minimum were 0.56 bees/ flower/ minute, whereas female flower abundance of bees was maximum 0.90 bees/ flower/ minute and $0.26 /$ bees/ minute (Fig. 3 ).

Maximum time spent by a forager per flower in male flower was 8.83 seconds and minimum were 3.99 seconds, while in female flower its maximum and minimum time spent was 5.65 and 2.60 seconds respectively (Table 2 ).

The peak foraging activity of $A$. cerana indica (No. of foragers visited / flower / $5 \mathrm{~min}$ ) was maximum (Fig. 4) during 06:00-10:00 $\mathrm{h}$ (1.21-2.29). The foraging activity gradually declined after 10:00-11:00 $\mathrm{h}$ (1.01) and no activity was observed between 17:00-18:00 $\mathrm{h}$. The declining of the activity between 12:00-17:00 $\mathrm{h}$ was mainly due to the nature of bitter gourd flowers, which starts drying at about 12:30 h (Deyto and Cervancia 2009).

\section{Pollination efficiency index}

Pollination efficiency of $A$. cerana indica was calculated by counting the number of loose pollen grains adhering on the body (130200 pollen grains), multiplying by the abundance $(0.88$ no. of foragers/minute) and by foraging rate of $A$. cerana indica (6.52). Pollination efficiency index of $A$. cerana indica was found to be 747035.5 (Table 3).

\section{Foraging activity of $\boldsymbol{A}$. cerana indica at hive entrance}

The foraging activity of $A$. cerana indica was recorded at the hive entrance in a day at a different time interval. The result revealed that the mean of incoming nectar foragers was higher (47.36) than incoming pollen foragers (16.5). Forager movement was maximum at $08: 00$ to $10: 00 \mathrm{~h}$ (53.8) followed by $12: 00$ to $13: 00 \mathrm{~h}(32.1)$ and minimum activity was at 16:00 to $18: 00$ h (33.53) (Table 4) (Fig. 5).

\section{Colony growth parameter of $\boldsymbol{A}$. cerana indica}

Colony growth parameter was recorded periodically in A. cerana indica hive kept in bitter gourd field. The result shows that increase in sealed honey area, pollen storage area, sealed brood and colony population. The colonies recorded $67.85 \%$ increase of sealed honey area, $45.9 \%$ increase in pollen area and $34.41 \%$ increase of sealed brood. Adult population also increased from 2244 to 3924 bees per hive which accounts for and $15.07 \%$ increase (Table 5).

\section{Effect of $A$. cerana indica on pollination and yield of bitter gourd}

The maximum fruit set was found to be in bee pollination condition and it was 17.4 fruits/plant while 16.2 fruits/plant on average was recorded in open pollination condition (T3). The fruit weight was higher $(255.3 \mathrm{~g} /$ fruit) in bee pollination (T2) than open pollination condition ( $248.6 \mathrm{~g} / \mathrm{fruit})$. The yield in bee pollination condition was $41.13 \mathrm{t} / \mathrm{ha}$ followed by open pollination condition (37.25t/ha). In pollinator exclusion (T1), no fruit set was observed under sleeve caged condition (Fig. 6) (Table 6).

Table 1. Abundance of Indian bees on bitter gourd

\begin{tabular}{|l|c|c|c|c|c|c|c|c|c|}
\hline \multicolumn{7}{|c|}{ No. of foragers/flower/ min \pm S.D } \\
\hline & $15^{\text {th }}$ day & $\mathbf{3 0 ^ { \text { th } }}$ day & $\mathbf{4 5 ^ { \text { th } }}$ day & $\mathbf{6 0 ^ { \text { th } }}$ day & $\mathbf{7 5 ^ { \text { th } }}$ day & $\mathbf{9 0 ^ { \text { th } }}$ day & $105^{\text {th }}$ day & $\mathbf{1 2 0 ^ { \text { th } }}$ day & Mean \\
\hline $\begin{array}{l}\text { Male } \\
\text { flower }\end{array}$ & $0.56 \pm 0.04$ & $0.67 \pm 0.071$ & $0.9 \pm 0.03$ & $1.05 \pm 0.15$ & $1.15 \pm 0.03$ & $0.97 \pm 0.014$ & $0.96 \pm 0.004$ & $0.81 \pm 0.091$ & 0.88 \\
\hline $\begin{array}{l}\text { Female } \\
\text { flower }\end{array}$ & $0.38 \pm 0.15$ & $0.26 \pm 0.07$ & $0.51 \pm 0.06$ & $0.55 \pm 0.17$ & $0.90 \pm 0.014$ & $0.88 \pm 0.15$ & $0.62 \pm 0.063$ & $0.60 \pm 0.05$ & 0.57 \\
\hline Mean & 0.47 & 0.47 & 0.68 & 0.80 & 1.03 & 0.92 & 0.79 & 0.65 & 0.73 \\
\hline
\end{tabular}

Note: *Mean of 10 plant observations; S.D: Standard Deviation 


\section{ARAŞTIRMA MAKALESI / RESEARCH ARTICLE}

Table 2. Foraging activity of Indian bee in bitter gourd

\begin{tabular}{|l|l|l|l|l|l|l|l|l|l|}
\hline \multicolumn{7}{|c|}{ Floral handling time (forager/flower/ min) in seconds \pm S.D } \\
\hline & $15^{\text {th }}$ day & $30^{\text {th }}$ day & $45^{\text {th }}$ day & $60^{\text {th }}$ day & $75^{\text {th }}$ day & $90^{\text {th }}$ day & $105^{\text {th }}$ day & $120^{\text {th }}$ day & Mean \\
\hline $\begin{array}{l}\text { Male } \\
\text { flower }\end{array}$ & $3.99 \pm 1.06$ & $5.36 \pm 0.8$ & $6.70 \pm 0.06$ & $6.23 \pm 0.103$ & $8.83 \pm 2.15$ & $7.65 \pm 0.14$ & $7.61 \pm 0.9$ & $5.82 \pm 0.6$ & 6.52 \\
\hline $\begin{array}{l}\text { Female } \\
\text { flower }\end{array}$ & $2.49 \pm 1.36$ & $3.61 \pm 0.74$ & $2.74 \pm 1.19$ & $2.60 \pm 0.702$ & $5.65 \pm 0.4$ & $4.70 \pm 0.13$ & $3.89 \pm 0.30$ & $3.20 \pm 0.84$ & 3.61 \\
\hline Mean & 3.24 & 4.48 & 4.72 & 4.42 & 7.24 & 6.18 & 5.75 & 4.51 & 5.07 \\
\hline
\end{tabular}

Note: *Mean of 10 plant observations; S.D: Standard Deviation

Table 3. Pollination efficiency index of $A$. cerana indica on bitter gourd

\begin{tabular}{|c|c|c|c|c|}
\hline Bee species & $\begin{array}{c}\text { Abundance } \\
\text { (No. of foragers/min) }\end{array}$ & $\begin{array}{c}\text { Foraging rate } \\
\text { (Foraging activity in } \\
\text { flower /seconds) }\end{array}$ & $\begin{array}{c}\text { Number of loose } \\
\text { pollen grains on the } \\
\text { body* }\end{array}$ & $\begin{array}{c}\text { Pollination index } \\
\text { (Abundance } \times \\
\text { Foraging rate } \times \text { Loose } \\
\text { pollen grains) }\end{array}$ \\
\hline A. cerana indica & 0.88 & 6.52 & 130200 & 747035.5 \\
\hline
\end{tabular}

Note: *Mean of five observations under stereo zoom microscope.

Table 4. Foraging activity of $A$. cerana indica at hive entrance during peak flowering period.

\begin{tabular}{|l|c|c|c|c|}
\hline Foraging Time & $08: 00-10: 00 \mathrm{~h}$ & $12: 00-13: 00 \mathrm{~h}$ & $16: 00-18: 00 \mathrm{~h}$ & Mean \\
\hline Incoming nectar forager & $\begin{array}{c}60.1 \\
(7.74)^{\mathrm{a}}\end{array}$ & $\begin{array}{c}32.4 \\
(5.69)^{\mathrm{c}}\end{array}$ & $\begin{array}{c}49.6 \\
(7.04)^{\mathrm{b}}\end{array}$ & 47.36 \\
\hline Incoming Pollen forager & $\begin{array}{c}33.2 \\
(5.758)^{\mathrm{a}}\end{array}$ & $\begin{array}{c}14 \\
(3.72)^{\mathrm{b}}\end{array}$ & $\begin{array}{c}23 \\
(1.492)^{\mathrm{c}}\end{array}$ & 16.5 \\
\hline Outgoing bees & 68.1 & 49.9 & 28 \\
$(7.04)^{\mathrm{b}}$ & $(5.27)^{\mathrm{c}}$ & 48.5 \\
\hline Mean & 53.8 & 32.1 & 33.53 & \\
\hline C.D. (P=0.05) & - & - & - & 0.346 \\
\hline
\end{tabular}

Note: *Mean of five observations, figures in parentheses are $\sqrt{(} \mathrm{x}+0.5)$ (square root) transformed values. In rows means followed by different alphabets are significantly different at $5 \%$ level LSD

Table 5. Colony growth parameter of $A$. cerana indica in bitter gourd

\begin{tabular}{|l|l|l|l|l|l|l|l|l|}
\hline $\begin{array}{l}\text { Days }(15 \\
\text { days } \\
\text { interval })\end{array}$ & $\begin{array}{l}\text { Sealed } \\
\text { honey } \\
\text { area }\left(\mathrm{cm}^{2}\right)\end{array}$ & $\begin{array}{l}\text { \% Increase } \\
\text { in sealed } \\
\text { honey area }\end{array}$ & $\begin{array}{l}\text { Pollen } \\
\text { storage } \\
\text { area }\left(\mathrm{cm}^{2}\right)\end{array}$ & $\begin{array}{l}\text { \% Increase } \\
\text { in pollen } \\
\text { storage } \\
\text { area }\end{array}$ & $\begin{array}{l}\text { Sealed } \\
\text { brood area } \\
\left(\mathrm{cm}^{2}\right)\end{array}$ & $\begin{array}{l}\text { \% Increase } \\
\text { in sealed } \\
\text { brood area }\end{array}$ & $\begin{array}{l}\text { Adult bee } \\
\text { population }\end{array}$ & $\begin{array}{l}\text { \% Increase } \\
\text { of bee } \\
\text { population }\end{array}$ \\
\hline 15 & 37 & - & 46 & - & 165 & - & 2244 & - \\
\hline 30 & 56 & 51.35 & 71 & 39.13 & 215 & 30.3 & 3410 & 51.96 \\
\hline 45 & 94 & 67.85 & 89 & 45.9 & 289 & 34.41 & 3924 & 15.07 \\
\hline
\end{tabular}

Note: *Mean of two observations. 


\section{ARAŞTIRMA MAKALESI / RESEARCH ARTICLE}

Table 6. Effect of different mode of pollination on bitter gourd yield

\begin{tabular}{|l|l|l|l|l|l|l|l|l|}
\hline $\begin{array}{l}\text { Modes of } \\
\text { pollination }\end{array}$ & $\begin{array}{l}\text { No. of female } \\
\text { flowers } \\
\text { Observed }\end{array}$ & $\begin{array}{l}\text { No. of } \\
\text { picking } \\
\text { /plant }\end{array}$ & $\begin{array}{l}\text { No. of } \\
\text { fruits } \\
\text { /plants }\end{array}$ & $\begin{array}{l}\text { Fruit } \\
\text { weight (g) }\end{array}$ & $\begin{array}{l}\text { \% Increase } \\
\text { in fruit } \\
\text { weight }\end{array}$ & $\begin{array}{l}\text { Yield of 10 } \\
\text { plants (kg) }\end{array}$ & $\begin{array}{l}\text { Yield } \\
\text { (t/ha) }\end{array}$ & $\begin{array}{l}\text { \% Increase } \\
\text { in yield } \\
\text { (t/ha) }\end{array}$ \\
\hline $\begin{array}{l}\text { Pollinator } \\
\text { Exclusion** }\end{array}$ & 350 & 0 & 0 & 0 & - & 0 & 0 & - \\
\cline { 2 - 9 } & $(0.71)^{\mathrm{c}}$ & $(0.71)^{\mathrm{c}}$ & $(0.71)^{\mathrm{c}}$ & - & $(0.71)^{\mathrm{c}}$ & - & - \\
\hline $\begin{array}{l}\text { Bee pollination } \\
\text { (A. cerana } \\
\text { indica) }\end{array}$ & 350 & 13.57 & 17.4 & 255.3 & 2.6 & 44.42 & 41.13 & 10.28 \\
\cline { 2 - 9 } & $(3.89)^{\mathrm{a}}$ & $(4.34)^{\mathrm{a}}$ & $(16.03)^{\mathrm{a}}$ & - & $(66.58)^{\mathrm{a}}$ & - & - \\
\hline $\begin{array}{l}\text { Open pollinated } \\
\text { condition }\end{array}$ & 350 & 10.86 & 16.2 & 248.6 & - & 40.27 & 37.25 & - \\
\cline { 2 - 10 } & & $(3.52)^{\mathrm{b}}$ & $(4.23)^{\mathrm{b}}$ & $(15.82)^{\mathrm{b}}$ & - & $(63.91)^{\mathrm{b}}$ & - & - \\
\hline S.E (d) & & 0.011 & & & & & & \\
\hline C.D. (P=0.05) & & 0.024 & & & & & & \\
\hline
\end{tabular}

Note: *Mean of five observations, ${ }^{* *}$ No fruit set was observed in pollinator e-xclusion. figures in parentheses are $\sqrt{(x+0.5)}$ (square root) transformed values. In columns, means followed by alphabet are significantly different at $5 \%$ level LSD.

\section{DISCUSSION}

Bees are the most reliable and utilized pollinators in bitter gourd. Managed pollination with honey bees is the effective method in which the bee hives shifted to the field at the time of flowering in $10 \%$ plants. The above-mentioned results of abundance of $A$. cerana indica was 0.73 bees/ flower/ minute (overall mean of male and female flower) and foraging activity was 5.07 seconds are in accordance with result of Yogapriya et al. (2019) who reported that the abundance of $A$. cerana indica in bitter gourd flowers was 0.90 individual/ $5 \mathrm{mins} / \mathrm{m}^{2}$ and the average time spent by the individual bee in each flower was 3.91 second.

Peak foraging activity of $A$. cerana indica was maximum at 06:00-10:00 $\mathrm{h}(1.21-2.29)$ and this is in line with the result of Yogapriya et al. (2019) who also observed the maximum foraging activity at 06:00-10:00 $\mathrm{h}\left(2.88 / \mathrm{m}^{2} / 5 \mathrm{~min}\right)$ and minimum activity at 14:00-16:00 h (0.345 seconds/ $\left.\mathrm{m}^{2} / 5 \mathrm{~min}\right)$. Nidangundi et al. (2005) reported that the foraging activity of $A$. cerana indica started from $08: 00 \mathrm{~h}$ and peak activity was recorded during 10:00 $\mathrm{h}$ (12.51 bees/ $\left.\mathrm{m}^{2} / 5 \mathrm{~min}\right)$. The maximum activity of $A$. cerana indica was also observed at 10:00 h with 3.69 bees/ $\mathrm{m}^{2} / 5 \mathrm{~min}$ (Jignesh and Pastagia 2021). Kumar et al. 2012, recorded the foraging activity of Halictus sp. at
08:00 - 10:00 h (3.47 bees $/ \mathrm{m}^{2} / 5$ mins) followed by Megachile sp. at 08:00 - 10:00 h $\left(2.07\right.$ bees $/ \mathrm{m}^{2} / 5$ mins) and minimum activity of $A$. dorsata at 08:00 10:00 h ( 1.67 bees $/ \mathrm{m}^{2} / 5$ mins).

Our results showed that pollination efficiency index A. cerana indica was 747035.5 are in line with Singh and Mall (2020) who observed that the activity of $A$. cerana indica in cucumber had a pollination efficiency index value of 320718.5. Kumar et al. (2019), also reported that in bitter gourd the maximum number of pollen grains in $A$. dorsata was 170000 (pollination index was 132600), followed by Megachile sp. 80000 pollen grains (84000 pollination index) Halictus sp. was 60000 (86400 pollination index).

Sowmiya et al. (2018) reported that sealed honey area was increased from 58.4 to $81.9 \mathrm{~cm}^{2}$, pollen storage area from 40.2 to $65.9 \mathrm{~cm}^{2}$, sealed brood area from 63.9 to $89.9 \mathrm{~cm}^{2}$ and adult population from 2171 to 3305 bees per hive when they were placed in moringa (Moringa oleifera) orchard during the experimental period which supports our finding that significant increase in sealed honey area, sealed brood, pollen area and colony population were recorded in Indian bee hive kept in bitter gourd field during the experiment. 


\section{ARAŞTIRMA MAKALESI / RESEARCH ARTICLE}

The results of present findings are in accordance with the result of Ngawang et al. (2017) who reported maximum fruit set of $87.14 \%$ under bee pollination condition and $65.21 \%$ under open pollination condition respectively. Deyto and Cervancia (2009) also recorded higher fruit set $78 \%$ in bitter gourd under natural pollination. The effect of bee pollination in bitter gourd with higher fruit weight of $129.20 \mathrm{~g}$ followed by open pollination condition $(72.09 \mathrm{~g})$ and $(62.44 \mathrm{~g})$ pollinator exclusion. The yield in bee pollination condition was 118.87 quintals followed by open pollination 68.63 and caged plots 45.23 without bees. Rajasekhar (2001) reported higher fruits of (22.37) per plot under managed pollination in watermelon, with two colony and 20.75 fruits one colony per plot.

\section{Conclusion}

Pollination deficit under open pollination condition is results in lower yield of bitter gourd. A. cerana indica is the effective managed pollinator of bitter gourd and its cross-pollination activity significantly enhances the yield parameters. Colony growth parameter of $A$. cerana indica was also increased during the period of experiment. Hence, managed bee pollination with $A$. cerana indica considered as can be best approach for the farmers as well as bee keepers to enhance the bitter gourd yield and honey yield respectively.

Source of finance for the study: There is no source of finance for this study.

Contribution of authors: I express my special thanks of gratitude to my chairman Dr. P.A. Saravanan and co-authors for their guidance in completing my research.

Declaration of conflict of interest: Authors have no conflict of interest to declare and all the coauthors have accepted the content.

\section{Acknowledgement}

I express my special thanks of gratitude to my chairman Dr. P.A. Saravanan and co-authors for their guidance in completing my research.

\section{REFERENCES}

Deyto, R. C., Cervancia, C. R. 2009. Floral biology and pollination of Ampalaya (Momordica charantia L.). Philipp. Agric. Sci. 92(1): 8-18.
Desphande, A. A., Venkatasubbaiah, K., Bankapur, V. M., Nalawadi, U.G. 1979. Studies on floral biology of bitter gourd (Momordica charantia L.). Mysore Journal of Agricultural Science. 13: 156-157.

Food and Agricultural Organization, 2015. $<$ https://www.fda.gov/animal-

veterinary/animal-health-literacy/helpingagricultures-helpful-honey-bees $>$

Jignesh, D. P., Pastagia, J.J. 2021. To study the pollinator fauna of bitter gourd and their foraging behaviour in natural pollination and augmentation of Apis cerana bees to natural pollination. J. Pharm. Innov. SP-10(6): 9195.

Kumar P., Surender K. S., Mahesh K. R. 2012. Diversity, abundance, and pollination efficiency of native bee pollinators of bitter gourd (Momordica charantia L.) in India. J. Apic. Res, 51(3): 227-231. http://dx.doi.org/10.3896/IBRA.1.51.3.02

Mohapatra, L. N., Sontakke, B. K., Ranasingh, N. 2010. Enhancement of Crop Production Through Bee Pollination. Orissa Review

Singh, M., Mall, P. 2020. Pollination Efficiency of Different Species on Cucumber (Cucumis sativus) in Tarai Region of Uttarakhand. Int. j. curr, microboil. appl. sci. 11: 2832-2839.

Manchare, R. R., Kulkarni, S. R., Patil, S. D. 2019. Effect of Bee pollination on Seed Yield and Yield Contributing Characters of Bitter Gourd Momordica Charantia L. Chem. sci. rev. lett. 8(30), 236-240.

Ngawang, D., Dharam P. A., Uma S. 2017. Insect Visitors on Cucumber and Bitter gourd Flowers and Impact on Quantity of Crop Production by Different pollination Treatment. J. Apic. Res. 32(2): 77-88.

Nidagundi, B. R., Sattagi, H. N. 2005. Pollinator Fauna and Foraging Activity of Bees in Bitter Gourd. Karnataka J Agric. Sci. 18(4): (982985).

Pal, U.R., Singh, U.R. and Maurya, R.A., 1972. Floral Biology of Bitter-Gourd. Indian J Hortic., 29(1), pp.73-76.

Rajasekhar, W. 2001. Exploration of domestic bees in enhancing the productivity of certain 


\section{ARAŞTIRMA MAKALESİ / RESEARCH ARTICLE}

crops Ph. D. Thesis, University of Agricultural Science, Dharwad.

Sowmiya, C., Srinivasan, M.R. and Saravanan, P.A., 2018. Diversity of Pollinators in Drumstick, Moringa oleifera Lam. Ecosystem. Madras Agric. J. 105(march (1-3)), p.1.
Yogapriya, A., Usharani, B., Suresh, K., Vellaikumar, S., Chinniah, C. 2019. Foraging Behaviour of Major Pollinators in Bitter Gourd. Int. j. curr, microboil. appl. sci. 8(6): 947-954. https://doi.org/10.20546/ijcmas.2019.806.1 14. 